\title{
MANAJEMEN PENGEMBANGAN MUTU LEMBAGA PENDIDIKAN Studi di Madrasah Ibtidaiyah Negeri (MIN) Tempel Yogyakarta
}

\author{
Alfian Eko Rochmawan \\ Institut Islam Mamba'ul 'Ulum Surakarta \\ alfianecko@gmail.com
}

\begin{abstract}
Islamic Elementary education institutions Negri Tempel is an institution engaged in education on the basis of Islamic education that is inseparable from the competition and competition from other Islamic educational institutions. Tempel State Islamic Elementary School is an institute under the auspices of the Ministry of Religion. The purpose of its establishment is to increase the intelligence, knowledge, personality, character, and skills to live independently and to follow further education, which is expected to be achieved and sustained total liability.

This study aims to present how the development of quality management in the State Government Elementary School Tempel covering Planing, Organizing, Actuating, Controlling. Inside analysis by looking kekutan institutions namely the implementation and development of quality educational institutions. The result is that the State Government Elementary School Tempel Yogyakarta has different characteristics with other agencies like Islamic Elementary. The development of quality educational institutions can be reviewed through the theory of planning, organizing, supervision or control. In plain practical management functions have been implemented in the State Islamic Elementary Tempel Yogyakarta and has been implemented effectively. Thus the implementation of the development of quality management education institutions in general have a direct impact on the management of the State Government Elementary School in Yogyakarta Tempel. Cooperation institutions have been embedded in every teachers, employees and students so as to produce graduates who are high achievers, moral qur'ani, confident, healthy and innovative environmentally sound.
\end{abstract}

Keywords: Development, Management, Institutions

\section{Pendahuluan}

Anak-anak merupakan penentu nasib sebuah bangsa di masa mendatang. Orang tua pada dasarnya menginginkan anak-anak mereka kelak menjadi individu yang sukses dan berguna bagi banyak orang. Harapan yang besar dari berbagai pihak mengenai generasi bangsa yang cerdas, tangguh, dan bermoral tentu menjadi perhatian yang serius. Perhatian yang lebih besar dari berbagai pihak menjadi sebuah langkah untuk mewujudkan generasi yang tangguh demi 
kemajuan sebuah bangsa di masa yang akan datang. Fenomena pelajar yang dapat diamati dan dilihat dari media masa seringnya merupakan hal yang negatif. Kasus kriminalitas pelajar adalah salah satu fakta yang memprihatinkan khususnya di dunia pendidikan. Laporan Direktorat III Tindak Pidana Umum Bareskrim Mabes Polri tahun 2011 menemkan terjadi 967 kasus kriminalitas pada anak dengan perkara antara lain penganiayaan, tindakan asusila, dan pencurian. Kriminalitas yang melibatkan pelajar tersebut menjadi isyarat terjadinya degradasi moral di Negara ini.

Kemerosotan moral yang terjadi memiliki beberapa faktor diantaranya lingkungan sosial, lingkungan keluarga, lingkungan sekolah. Lingkungan sekolah secara langsung memiliki peran penting dalam menanamkan karakter. Karakter yang baik merupakan motivasi untuk berbuat baik, setuju terhadap perilaku berbudi luhur dalam setiap situasi (Suwarna 2014: 137-147). Karakter yang ditanamkan melalui lingkungan sekolah diharapkan mampu mengurangi terjadinya kriminalitas yang dilakukan oleh para pelajar. Lembaga pendidikan merupakan wadah pembentuk karakter siswa sekaligus yang bertanggung jawab mendidik dan mengembangkan potensi siswa. Potensi-potensi yang ada didalam diri siswa dikembangkan sedemikian rupa sehingga terbentuk siswa yang cerdas dan berkarakter. Sekolah merupakan salah-satu dari Tripusat pendidikan yang dituntut untuk mampu menjadikan output yang unggul, dimana terdapat sejumlah orang bekerja sama dalam rangka mencapai tujuan sekolah yang dikenal sebagai tujuan instruksional (Ulmunir 2010:93). Manajemen peningkatan mutu merupakan alternatif untuk pengelolaan pendidikan yang lebih menekankan kepada kemandirian dan kreatifitas lembaga pendidikan.

Konsep pendidikan pengertian mutu adalah mencakup input, proses, output pendidikan. Input pendidikan adalah segala sesuatu yang harus ada karena kebutuhan untuk berlangsungnya proses (peralatan,perlengkapan, uang, bahan, dan lain-lain). Madrasah Ibtidaiyah merupakan lembaga pendidikan dasar yang berbasis keislaman. Seiring berkembangnya zaman madrasah harus dapat mengikuti arus perkembangan global agar dapat bertahan. Dalam perkembangannya madrasah dituntut untuk dapat mengembangkan mutu 
lembaganya. Madrasah Ibtidaiyah Negeri (MIN) Tempel merupakan salah satu madrasah yang ditunjuk oleh kanwil DIY sebagai Rintisan Madrasah Unggul RMU berdasarkan SK. Kakanwil DIY No. 6098 Tahun 2012. Dalam perjalanannya Madrasah ini terus berkembang dan berkompetisi seiring berkembangnya zaman.

MIN Tempel merupakan Madrasah yang dapat menjadi tauladan bagi madrasah yang lain terlihat dari banyaknya prestasi yang diraihnya baik dari tingkat kecamatan, kabupaten maupun nasional, pengembangan yang dilakukan berkesinambungan dari waktu ke waktu baik dari guru, siswa, sarana dan prasarana. Dari hal tersebut, maka penulis tertarik dan ingin menganalisis secara mendalam bagaimana pengembangan manajemen mutu lembaga di MIN Tempel, Ngaglik, Sleman, Yogyakarta. Apa kendala yang dihadapi oleh kepala Madrasah dan apa saja faktor pendukung dan penghambat dalam peningkatan mutu lembaga. Bedasarkan permasalahan tersebut diatas maka judul penelitian ini adalah Manajemen Pengembangan Mutu Lembaga Pendidikan (Studi di MadrasahIbtidaiyah Negeri Tempel Yogyakarta) Untuk lebih jelasnya peneliti rumuskan sebagai berikut : Pertama, Bagaimana pelaksanaan manajemen pengembangan mutu lembaga pendidikan di MIN TEMPEL, Ngaglik, Sleman, Yogyakarta? Kedua, Faktor apa yang mendukung pengembangan mutu lembaga di MIN TEMPEL, Ngaglik, Sleman, Yogyakarta? Ketiga, Faktor apa yang menghambat pengembangan mutu lembaga di MIN TEMPEL, Ngaglik, Sleman, Yogyakarta?

\section{Kerangka Teoritik}

Manajemen berasal dari bahasa latin, yaitu asal kata manus yang berarti tangan dan agere yang berarti melakukan. kata-kata itu di gabungkan menjadi kata kerja managere yang artinya menangani. Managere diterjemahkan kedalam bahasa inggris dalam bentuk kerja to manage, dengan kata benda management. akhirnya management diterjemahkan kedalam bahansa Indonesia menjadi manajemen atau pengelolaan (Jahari, 2013 : 1). Manajemen merupakan suatu penyelesaian aktifitas secara efisien dengan melalui orang lain dan berkaitan dengan rutinitas tugas atau organisasi (Denim, $2009: 3$ ). 
Adapun secara terminologis definisi manajemen dikemukakan oleh para ahli dengan redaksi yang berbeda - beda diantaranya yang pertama : Menurut G.RTerry (2009:1) manajemen adalah suatu proses yang terdiri dari perencanaan, pengorganisasian, penggerakan pelaksanaan dan pengawasan dengan memanfaatkan baik ilmu maupun seni agar dapat menyelesaikan tujuan yang telah ditetapkan sebelumnya. Kedua, Menurut Horold Koontz dan Cyril O’donnel (1992), manajemen berhubungan dengan pencapaian suatu tujuan yang dilakukan melalui dan dengan orang-orang yang lain. Dengan kata lain manajemen adalah usaha mencapai suatu tujuan tertentu melalui kegiatan orang lain. Ketiga, MenurutJames A.F Stoner (1982 :3) manajemen adalah proses perancanaan, pengorganisasian, pengarahan, dan pengawasan usaha-usaha para anggota organisasi dan penggunaan sumber daya- sumber daya organisasi lainnya agar mencapai suatu tujuan yang telah ditetapkan . keempat, Menurut Laurence A . Appley mengatakan manajemen adalah seni mencapai tujuan dilakukan melalui usaha orang lain. Kelima, Menurut Oey Liang Lee, Manajemen adalah seni dan ilmu perencanaan pengorganisasian, penyusunan, pengarahan dan pengawasandaripada sumber daya manusia untuk mencapai tujuan yang telah ditetapkan. Keenam, Menurut Luther Gulick (1981: 2).

Manajemen sebagai ilmu, profesi dan kiat. Dikatakan ilmu, karena manajemen dipandang sebagai bidang ilmu pengetahuan yang secara sistimatis berusaha memahami mengapa dan bagaimana orang bekerja sama. Disebut sebagai kiat, karena manajemen mencapai sasaran dengan cara-cara mengatur orang lain dalam menjalankan tugas. Dan dipandang sebagai profesi, karena manajemen dilandasi oleh keahlian khusus untuk mencapai prestasi manajer dan para professional dituntut oleh suatu kode etik (jahari, 2013 : 2). Dalam definisi yang lain manajemen diartikan sebagai proses merencanakan dan mengambil keputusan, memimpin dan mengendalikan sumberdaya manusia, keuangan, fasilitas dan informasi guna mencapai sasaran organisasai dengan cara efisien dan efektif (Atmodiwiryo, $2000: 5$ ).

\section{Pengembangan Mutu}


Pengembangan makna proses, cara, perbuatan untuk mengembangkan. Pengembangan yang dimaksudkan disini adalah suatu proses yang dilakukan oleh seseorang atau kelompok dengan cara-cara tertentu untuk mencapai tujuan tertentu. Mutu berasal dari bahasa latin, gualis. Mutu menurut Deming adalah kesesuaian menurut pasar. W. Edwards Deming mengemukakan tentang Mutu bersifat Filsafat. Dalam bukunya yang berjudul Out of the Crisis, beliau menggabungkan konsep Mutu mulai dari wawasan Psikologis sampai dengan Kultur Mutu (Quality Culture). Deming menyatakan, ada empat belas poin manajemen mutu yaitu pertama, Ciptakan sebuah usaha peningkatan produksi dan jasa. Kedua, Adopsi falsafah baru. Ketiga, Hindari ketergantungan pada inspeksi massa untuk mencapai mutu. Keempat, Akhiri praktek menghargai bisnis dengan harga. Kelima, Tingkatkan secara konstan sistem produksi dan jasa. Keenam, Lembagakan pelatihan kerja. Ketuju, Lembagakan kepemimpinan. Kedelapan, Hilangkan rasa takut. Kesembilan, Uraikan kendala-kendala antar departemen. Kesepuluh, Hapuskan slogan, desakan, dan target, serta tingkatkan produktifitas tanpa menambah beban kerja. Kesebelas, Hapuskan standar kerja yang menggunakan quota numerik. Keduabelas, Hilangkan kendala-kendala yang merampas kebanggaan karyawan atas keahliannya. Ketigabelas, Lembagakan aneka program pendidikan yang meningkatkan semangat danpeningkatan kualitas kerja. Keempatbelas Tempatkan setiap orang dalam tim kerja agar dapat melakukan transformasi (Salis, 2008: 34).

\section{Lembaga Pendidikan}

Menurut Kamus bahasa Indonesia, pengertian dari lembaga adalah badan organisasi yang bertugas mengadakan penlitian atas pengembangan ilmu. Pengertian pendidikan adalah usaha sadar dan terencana untuk mewujudkan suasana belajar dan proses pembelajaran agar peserta didik secara aktif mengembangkan potensi dirinya untuk memiliki kekuatan spiritual keagamaan, pengendalian diri, kepribadian, kecerdasan, akhlak mulia, serta ketrampilan yang diperlukan dirinya dan masyarakat. jadi lembaga pendidikan adlah suatu badan 
atau organisasi yang bertugas untuk mengatur secara sistematis dalam bidang pendidikan pada masyarakat dalam menunjang pertumbuhan jasmani maupun rohaninya untuk mencapai tingkat dewasa.

Dalam upaya meningkatkan mutu sumber daya manusia, mengejar ketertinggalan di segala aspek kehidupan dan menyesuaikan dengan perubahan global serta perkembangan ilmu pengetahuan dan teknologi, bangsa Indonesia melalui DPR dan Presiden pada tanggal 11 Juni 2003 telah mensahkan Undangundang Sistem Pendidikan Nasional yang baru, sebagai pengganti Undang- undang Sisdiknas Nomor 2 Tahun 1989. Undang-undang Sisdiknas Nomor 20 Tahun 2003 yang terdiri dari $22 \mathrm{Bab}$ dan 77 pasal tersebut juga merupakan pengejawantahan dari salah satu tuntutan reformasi yang marak sejak tahun 1998. Perubahan mendasar yang dicanangkan dalam Undang-undang Sisdiknas yang baru tersebut antara lain adalah demokratisasi dan desentralisasi pendidikan, peran serta masyarakat, tantangan globalisasi, kesetaraan dan keseimbangan, jalur pendidikan, dan peserta didik.

Sebagai sistem sosial, lembaga pendidikan harus memiliki fungsi dan peran dalam perubahan masyarakat menuju ke arah perbaikan dalam segala lini. Dalam hal ini lembaga pendidikan memiliki dua karakter secara umum. Pertama, melaksanakan peranan fungsi dan harapan untuk mencapai tujuan dari sebuah sitem. Kedua mengenali individu yang berbeda-beda dalam peserta didik yang memiliki kepribadian dan disposisi kebutuhan (Hamalik, 2005 : 23). Kemudian sebagai agen perubahan lembaga pendidikan berfungsi sebagai alat pengembangan pribadi, pengembangan warga, pengembangan budaya, pengembangan bangsa. Upaya mewujudkan kesejahteraan masyarakat pada dasarnya merupakan cita-cita dari pembangunan bangsa. Kesejahteraan dalam hal ini mencakup dimensi lahir batin, material dan spiritual. Lebih dari itu pendidikan menghendaki agar peserta didiknya menjadi individu yang menjalani kehidupan yang aman dan damai. Oleh karena itu pembangunan lembaga pendidikan diharapkan dapat memberikan kontribusi nyata dalam mewujudkan Indonesia yang aman, damai, dan sejahtera. Sejalan dengan realitas kehidupan sosial yang berkembang di masyarakat, maka pengembangan nilai-nilai serta peningkatan 
mutu pendidikan tentunya menjadi tema pokok dalam rencana kerja pemerintah dalam membangun lembaga pendidikan.

Lembaga pendidikan di Indonesia dalam UU bisa kita klasifikasikan menjadi dua kelompok yaitu: sekolah dan luar sekolah. Selanjutnya pembagian ini lebih rincinya menjadi tiga bentuk informal, formal dan nonformal. Ketiga klasifikasi di atas dalam pergumulanya di masyarakat memiliki peran yang berbedabeda. Lembaga pendidikan pertama, yaitu informal atau keluarga, ranah garapanya adalah lebih banyak di arahkan dalam pembentukan karakter atau keyakinan dan norma. Lembaga pendidikan kedua, yaitu formal atau sekolah, peran besarnya lebih banyak di arahkan pada pengembangan penalaran murid. lembaga pendidikan ketiga, yaitu masyarakat, perannya lebih banyak pada pembentukan karakter social (Ahmadi, 2002 : 183-184).

Ketiga pembagian di atas adalah merupakan perubahan mendasar, penjelasan dari klasifikasi tersebut adalah (1) pendidikan informal, atau pendidikan pertama adalah kegiatan pendidikan yang dilakukan oleh keluarga dan lingkungan yang berbentuk kegiatan belajar secara mandiri, hal ini adalah menjadipendidikan primer bagi peserta dalam dalam pembentukan karakter dan kepribadian, (2) Pendidikan nonformal, atau pendidikan kedua meliputi pendidikan kecakapan hidup, pendidikan anak usia dini, pendidikan kepemudaan, pendidikan pemberdayaan perempuan, pendidikan keaksaraan, pendidikan keterampilan dan pelatihan kerja, pendidikan kesetaraan, serta pendidikan lain yang ditujukan untuk mengembangkan kemampuan peserta didik. Satuan pendidikan nonformal meliputi lembaga kursus, lembaga pelatihan, kelompok belajar, pusat kegiatan belajar masyarakat (PKBM), dan majelis taklim, serta satuan pendidikan yang sejenis. Hasil pendidikan nonformal dapat dihargai setara dengan hasil program pendidikan formal setelah melalui proses penilaian penyetaraan oleh lembaga yang ditunjuk oleh pemerintah (pusat) dan pemerintah daerah dengan mengacu pada standard nasional pendidikan. Adapun pendidikan nonformal diselenggarakan bagi warga masyarakat yang memerlukan layanan pendidikan yang berfungsi sebagai pengganti, penambah, atau ingin melengkap pendidikan formal dalam rangka mendukung pendidikan sepanjang hayat, yang 
berfungsi mengembangkan potensi peserta didik dengan penekanan pada penguasaan pengetahuan dan keterampilan fungsional serta pengembangan sikap dan kepribadian professional. (3) Jalur formal adalah lembaga pendidikan yang terdiri dari pendidikan dasar, pendidikan menengah, dan pendidikan tinggi dengan jenis pendidikan umum, kejuruan, akademik, profesi, advokasi dan keagamaan.

Pendidikan formal dapat coraknya diwujudkan dalam bentuk satuan pendidikan yang diselenggarakan oleh pemerintah (pusat), pemerintah daerah dan masyarakat. Pendidikan dasar yang merupakan jenjang pendidikan yang melandasi jenjang pendidikan menengah berbentuk lembaga sekolah dasar (SD) dan madrasah ibtidaiyah (MI) atau bentuk lain yang sederajat, serta sekolah menengah pertama (SMP) dan madrasah tsanawiyah (Mts) atau bentuk lain yang sederajad. Sebelum memasuki jenjang pendidikan dasar, bagi anak usia 0-6 tahun diselenggarakan pendidikan anak usia dini, tetapi bukan merupakan prasyarat untuk mengikuti pendidikan dasar. Pendidikan anak usia dini dapat diselenggarakan melalui jalur formal (TK, atau Raudatul Athfal), sedangkan dalam nonformal bisa dalam bentuk ( TPQ, kelompok bermain, taman/panti penitipan anak) dan/atau informal (pendidikan keluarga atau pendidikan yang diselenggarakan oleh lingkungan.

Pendidikan menengah yang merupakan kelanjutan pendidikan dasar terdiri atas, pendidikan umum dan pendidikan kejuruan yang berbentuk sekolah menengah atas (SMA), madrasah aliyah (MA), sekolah menengah kejuruan (SMK), dan madrasah aliyah kejuruan (MAK) atau bentuk lain yang sederajad. Selanjutnya adalah pendidikan tinggi yang merupakan jenjang pendidikan setelah pendidikan menengah, pendidikan ini mencakup program pendidikan Diploma, Sarjana, Magister, Doktor. Secara umum lembaga-lembaga tinggi ini dibentuk dandiformat untuk menyelenggarakan pendidikan, penelitian dan pengabdian pada masyarakat, serta menyelenggarakan program akademik, profesi dan advokasi. Semua lembaga formal di atas diberi hak dan wewenang oleh pemerintah untuk memberikan gelar akademik kepada setiap peserta didik yang telah menempuh pendidikan di lembaga tersebut. Khusus bagi perguruan tinggi yang memiliki program profesi sesuai dengan program pendidikan yang diselenggarakan doktor 
berhak memberikan gelar doktor kehormatan (doktor honoris causa) kepada individu yang layak memperoleh penghargaan berkenaan dengan jasa-jasa yang luar biasa dalam bidang ilmu pengetahuan, teknologi, kemasyarakatan, keagamaan, kebudayaan, atau seni.

\section{Pembahasan}

\section{Penerapan Manajemen Mutu MIN Tempel Yogyakarta}

Pertama, Perencanaan kegiatan Mutu MIN Tempel yang ada berasal dari koordinasi yang dilakukan dari berbagai pihak diantaranya, kepala madrasah, guru, karyawan dan wali murid yang dilaksanakan pada awal tahun pelajaran. Dalam rapat tersebut dirumuskan kegiatan yang akan dilaksanakan pada setahun dan ditunjuk koordinator pada setiap kegiatan. Madrasah Ibtidaiyah Tempel memiliki pembagian tugas perencanaan mutu yang sangat jelas dari setiap program yang direncanakan. Kedua, Perencanaan Program Madrasah, Kepala Madrasah yang menjadi penanggung jawab dalam perencanaan program madrasah. Kepala madrasah berkerjasama dengan seluruh komponen sekolah diantaranya Komite madrasah, Wakil Manajemen Mutu (WMM), Koordinator Bidang (Kobid), Kepala Tata Usaha (KTU) dan Tim ISO dengan sumberdana yang berasal dari RAPBM.

Ketiga, Perencanaan Pemasaran Perencanaan pemasaran yang dimaksud adalah melakukan sosialisasi kepada stakeholders. Koordinator Bidang Humas yang menjadi penanggung jawab atas berlangsungnya kegiatan tersebut. Koordinator bidang humas merencanakan jadwal kegiatan yang akan dilakukan dan media apa saja yang dibutuhkan untuk melakukan pemasaran. Keempat, Perencanaan Penerimaan Peserta Didik, Pada perencanaan peserta didik meliputi beberapa kegiatan diantaranya persiapan untuk pendaftaran, seleksi, penentuan calon peserta didik yang diterima.perencanaan terkait penerimaan peserta didik baru harus dilakukan secara tepat dan jelas, meliputi jadwal, sarana dan prasarana. Koordinator bidang pembiayaan dan Koordinator bidang kesiswaan menjadi penanggung jawab untuk memastikan keterlaksanaan kegiatan ini. Kelima, Perencanaan Proses Pendidikan kelas 1 s.d 6. 
Dalam keberlangsungan program ini adalah tanggung jawab seluruh guru mata pelajaran dimana didalamnya terkait bagaimana persiapan sebelum proses pembelajaran. Proses pembelajaran dapat berlangsung secara kondusif apabila perencanaan dan acuan yang ada sudah terstruktur dengan baik. Perencanaan pendidikan sudah dipersiapkan dengan baik terbukti dengan adanya kalender pendidikan, Kurikulum, Silabus, RPP dan Buku ajar. Kelima, Perencanaan Pendampingan, Untuk memastikan kualitas dan ketercapaian perlu diadakan pendampingan. Pendampingan dilakukan dalam beberapa hal diantaranya, pendampingan dalam hal pelaksanaan proses pembelajaran dan pendampingan dalam proses managerial lembaga. Dengan adanya proses pendampingan diharapkan program-program yang direncanakan berjalan dengan baik dan menghasilkan output yang sesuai dengan target pencapaian pendidikan di MIN Tempel.

Keenam, Perencanaan Perlindungan Untuk menjamin perlindungan pada setiap anggota lembaga pendidikan MIN Tempel bekerjasama dengan pihak asuransi. Dalam hal ini yang bertanggung jawab atas keterlaksanaan program tersebut adalah Kepala Madrasah dan Koordinator bidang kesiswaan. Ketujuh, Perencanaan Evaluasi Belajar, Pembelajaran yang berlangsung diharapkan dapat meningkatkan pengetahuan bagi peserta didik. Untuk mengetahui sejauhmana pemahaman peserta didik maka dibentuklah tim evaluasi belajar agar hasil belajar dapat diketahu secara jelas. Tugas dari tim tersebut adalah merencanakan dan melaksanakan proses evaluasi belajar.

Kedelapan, Perencanaan Verifikasi, Verifikasi merupakan rapat penegasan tentang kenaikan / kelulusan siswa. Rapat tersebut dihadiri oleh kepala madrasah dan seluruh dewan guru. Dalam rapat tersebut perencanaan yang dilakukan adalah menetapkan kriteria kenaikan/kelulusan. Hasil dari rapat tersebut pada nantinya akan menjadi setandar yang digunakan untuk menaikkan atau meluluskan siswa. Kesembilan, Pengorganisasian Pengorganisasian adalah jalan yang ditempuh oleh suatu kelompok untuk mewujudkan tujuan bersama. Dalam lembaga pendidikan tujuan bersama yang direncanakan adalah untuk mencapai tujuan pendidikan. Dalam hal itu lembaga pendidikan harus melaksanakan pengorganisasian dengan 
baik agar tujuan tersebut terlaksana dengan baik dan pada akhirnya target-target pendidikan tercapai. Pengorganisasian lembaga pendidikan melibatkan kerjasama seluruh komponen lembaga pendidikan baik dari peserta didik, guru, pegawai, kepala madrasah, komite, dan wali murid. Kerjasama yang baik dari seluruh komponen lembaga pendidikan akan menghasilkan keharmonisan dalam melaksanakan perencanaan dalam rangka mencapai tujuan.

\section{Pengembangan Manajemen Siswa}

Komponen Pengembangan Manajemen siswa MIN Tempel berupa Penerimaan peserta didik baru merupakan kegiatan penting bagi suatu madrasah, karena peristiwa ini merupakan titik awal yang menentukan kelancara tugas suatu madrasah. Hasil pelaksanaan penerimaan peserta didik baru dapat menentukan sukses tidaknya manajemen madrasah. Olehkarenanya dalam proses penerimaan peserta didik baru harus direncanakan dengan sebaik mungkin. Yaitu ketika menjelang tahun ajaran baru penerimaan peserta didik baru harus sudah selesai, untuk itu maka penunjukan panitia penerimaan peserta didik baru oleh kepala madrasah harus sudah selesai sebelum tahun ajaran berakhir. Pelaksanaan penerimaan peserta didik baru di MIN Tempel sudah direncanakan dengan sebaik mungkin yaitu dengan menunjuk panitia dan menentukan jadwal pelaksanaan kegiatan penerimaan peserta didik baru. MIN Tempel melaksanakan kegiatan penerimaan peserta didik baru melalui dua gelombang dimana gelombang pertama yaitu pada tanggal 1 februari sampai dengan 7 maret 2015 sedangkan gelombang ke dua menyesuaikan dengan kalender pendidikan dinas.

Dalam proses pelaksanaan kegiatan penerimaan peserta didik baru min tempel mencantumkan beberapa persyaratan yang harus dimiliki oleh calon peserta didik diantaranya : Akta kelahiran/surat kenal lahir dan kartu keluarga, Usia minimal 6 tahun pada tangal 13 Juli 2015, Mengisi blangko penjaringan yang disediakan dan Bersedia mengikuti tes seleksi sesuai dengan waktu yang telah dijadwalkan. Persyaratan-persyaratan tersebut merupakan persyaratan minimal yang harus dimiliki siswa untuk memudahkan data administrasi siswa yang terkait didalamnya untuk melaporkan data pokok pendidikan nasional. 
Selain persyaratan tersebut siswa juga diharuskan untuk mengikuti kegiatan dan tes seleksi yang telah direncanakan madrasah sesuai dengan waktu yang telah dijadwalkan yaitu : Seleksi tertulis yang dilaksanakan pada 22 Maret 2015, Seleksi wawancara yang dilaksanakan pada 27-28 Maret 2015, Pengumuman yang dilaksanakan pada 4 April 2015, Daftar ulang yang dilaksanakan pada 13-15 April 2015 dan Masa orientasi wali Murid yang dilaksanakan pada 4 Juli 2015.

Dengan mengikuti seluruh rangkaian kegiatan seleksi tersebut diharapkan sekolah mampu memenuhi target yang ditentukan serta dapat menganalisis bakat dan kemampuan tertentu peserta didik yang baru. Selain kegiatan seleksi didalamnya juga terdapat kegiatan-kegiatan yang lain diantaranya pengumuman, daftar ulang, dan prientasi wali murid. Kegiatan pengumuman di MIN Tempel merupakan kegiatan pemberitahuan hasil seleksi yang menentukan sudah memenuhi syaratkah peserta didik yang baru untuk mengikuti pembelajaran di Madrasah. Setelah adanya pengumuman, untuk memperoleh kepastian apakah pesetra didik baru betul-betul akan mengikuti pembelajaran di MIN Tempel, maka panitia penerimaan meminta kepada calon yang diterima untuk mendaftarkan kembali. Masa orientasi wali murid merupakan kegiatan pengenalan yang direncanakan Madrasah untuk menyampaikan program-program kerja yang akan dilaksanakan di madrasah tersebut kepada wali murid. Pertemuan ini menjelaskan kegiatan-kegiatan secara rinci. Terkait kurikulum yang akan di gunakan, tenaga pendidik yang mengampu, program khusus, ekstra kurikuler dan kegiatan yang lain yang berhubungan dengan Madrasah. Kegiatan masa orientasi wali murid dilaksanakan 3 hari untuk kelas 1 ada oriantasi pengenalan lapangan. Kemuian untuk kelas 2 dan yang lainnya ada kegiatan tersendiri yaitu pengenalan wali kelas baru dan kelas baru.

Pada proses perkembangan penerimaan peserta didik baru MIN Tempel mengalami Perkembangan yang siknifikan dapat terlihat pada jumlah pendaftar yang meningkat dari tahun ke-ketahun. Pada tahun 2014/2015 jumlah pendaftar yaitu 225 siswa, jumlah siswa yang diterima 96 siswa, sedangkan pada tahun 2015/2016 mencapai 350 siswa, jumlah siswa yang diterima 96 siswa. Daftar jumlah peserta didik tiga tahun terakhir yaitu tahun 2012 berjumlah 574, 2013 
berjumlah 568, 2014 berjumlah 565. Terlihat dari data tersebut bahwa dari tahun ketahun jumlah siswa mengalami penurunan. Jumlah penurunan peserta didik tersebut disebabkan karena adanya SPM (Standar peaksanaan Minimal) yaitu adanya pembatasan jumlah siswa setiap kelasnya pada jumlah 28 - 32 siswa.

\section{Perkembangan Penerapan Kurikulum Pembelajaran}

Dalam penerapan pembelajaran di MIN Tempel Menggunakan dua kurikulum yaitu : kurikulum KTSP dan Kurikulum 2013. Dalam pelaksanaannya kurikulum KTSP digunakan untuk kelas 2,3,5, dan 6. Sedangkan kurikulum 2013 digunakan untuk kelas 1 dan kelas 4. Pelaksanaan kurikulum KTSP dari tahun ketahun mengalami perkembangan terkait Nilai Kriteria Ketuntasan Minimal (KKM) dari masing-masing bidang studi yang ada. Penentuan keriteria ketuntasan minimal ini berdasarkan hasil rapat guru serumpun dan kemampuan siswa dalam satu kelas disetujui kepala madrasah. Pelaksanaan kurikulum 2013 merupakan tahap perkembangan kurikulum di MIN Tempel. Pada pelaksanaannya terdapat beberapa perbedaan dengan kurikulum KTSP diantaranya dalam pendekatan. Pendekatan yang digunakan adalah pendekatan ilmiah (Saintific Approach) yaitu standar proses dalam pembelajaran terdiri dari mengamati, menanya, mengolah, menyajikan, menyimpulkan, dan mencipta. Penilaian hasil belajar adalah dengan menggunakan penilaian autentik (authentic assessment) Standar penilaian otentik yaitu mengukur semua kompetensi sikap, keterampilan, dan pengetahuan berdasarkan proses dan hasil. Pada aspek kompetensi lulusan dimana jika pada kurikulum KTSP menekankan pada aspek pengetahuan namun berbeda dengan Kurikulum 2013 yan menuntut ada keseimbangan antara soft skills dan dard skills yang meliputi aspek komperensi sikap, keterampilan, dan pengetahuan.

\section{Perkembangan Pelaksanaan Bimbingan dan konseling}

Pada tahun 2013/2014 pelaksanaan penyuluhan/bimbingan (BK) dan konseling di MIN Tempel dilaksanakan oleh Guru khusus bimbingan dan konseling namun, dikarenakan ditingkat satuan pendidikan dasar tidak ada peraturan yang terkait dengan pengkhususan Guru bimbingan dan konseling, 
Selanjutnya Guru bimbingan dan konseling ditahun 2014/2015 sampai sekarang dilimpahkan pada Wali Kelas masing-masing. Bimbingan penyuluhan/bimbingan konseling di MIN TEMPEL dilaksanakan oleh masing-masing wali kelas disetiap kelasnya. Bimbingan dilaksanakan setelah habis jam pembelajaran atau pada jam pelajaran jika permasalahannya harus langsung ditangani. Bimbingan bisa dilaksanakan didalam kelas maupun luar kelas (home visit). Bimbingan diberikan kepada seluruh siswa di awal pelajaran secara klasikal pada kelas tersebut. Bimbingan berupa bimbingan pada semua permasalahan siswa baik positif maupun tindakan negative.

Bimbingan positif bisa berupa motovasi belajar ataupun bimbingan untuk tindak lanjut sekolah lulusan MIN TEMPEL. Bimbingan negative dilakukan jika ada siswa yang mempunyai masalah baik dengan siswa lain, guru pengampu pelajaran, atau membuat masalah sehingga pembelajaran tidak berjalan dengan lancar. Selain permasalahan didalam kelas, wali kelas bertugas untuk memberikan bimbingan untuk siswa yang melakukan pelanggaran peda tata tertib madrasah. Tindakan bimbingan disesuaikan dengan masalah/kejadian yang dialami siswa, jika bimbingan langsung dengan siswa tidak berhasil/maksimal, bimbingan dilanjutkan dengan pemanggilan orang tua /wali siswa.

\section{Perkembangan Pelaksanaan Ektra Kurikuler}

Kegiatan ekstra kurikuler di bentuk dalam rangka pengoptimalan bakat dan minat peserta didik. Adapun Kegiatan extra kurikuler di MIN TEMPEL meliputi: Jarimatika, Hadroh, Tenis meja, English Club, Lukis, Seni jawa, Arabic club, Qiro'ah, BTAQ, Pencak silat, Badui, Catur, Pramuka, Matematika, Tahfidzul Qur'an dan Tahsin Al-qur'an. Peserta dan pembimbing Extra kurikuler adalah siswa kelas I-V dengan ketentuan setiap anak diwajibkan mengikuti 1 (satu) kegiatan extra dan maksimal 3 jenis kegiatan. Adapun ketentuan pesertadan pembimbing kegiatan adalah: Jarimatika (kelas I-III pembmbing dari TIM Jarimatika), Hadroh (kelas I-V pembmbing bapak Nasrudin, A.Md), Tenis meja (kelas III-IV pembimbing bapak Dedi Ishaq), English Club (kelas I-IV pembmbing Elly Fatmawati), Lukis (kelas I-IV pembimbing bapak Rofi), Seni 
Jawa (kelas I-IV pembmbing bapak Bambang), Arabic Club (kelas I-IV pembimbing bapak Muh. Kharis) Qiro'ah (kelas I-IV pembmbing bapak Suparmanto) BTAQ (Kelas I-IV pembmbing dari TIM BTAQ) Pencak silat (Kelas I-V pembmbing bapak Syarif) Badui (Kelas I-III pembmbing bapak Nurkholis ) Catur (Kelas III-IV pembmbing bapak Nurdin) Pramuka (Kelas III-V pembmbing dari TIM Pramuka) Matematika (Kelas III-IV pembmbing ibu Supri) Tahfidzul Qur'an (Kelas III-V bimbingan dari Pondok Pesantren Ki Ageng Giring) Tahsin Al-qur'an (Kelas VI pembimbing dari TIM BTAQ).

Pelaksanaan kegiatan Extra kurikuler baik hari maupun jam kegiatan disesuaikan dengan jadwal belajar peserta kegiatan. Untuk kelas I dan II dimulai dari pukul 12.00 - 13.30, sedangkan kelas III dan IV dimulai pukul 13.00 - 14.30. Kegiatan BTAQ wajib diikuti oleh siswa kelas I dan II, sedangkan untuk siswa kelas III-IV diwajibkan bagi siswa yang belum bisa membaca Al-qur'an, dengan harapan out put MIN TEMPEL sudah bisa membaca Al-qur'an. Kegiatan extra matematika diikuti oleh siswa yang telah ditunjuk oleh guru mata pelajaran matematika pada kelas tersebut, sedangkan untuk kegiatan Tahfidzul Qur'an diikuti oleh siswa MIN TEMPEL melalui tes seleksi hafalan Al-qur'an. Untuk kegiatan Tahsin Al-qur'an diikuti oleh semua siswa kelas IV.

\section{Kesimpulan}

Berdasarkan apa yang telah peneliti paparkan pada hasil pennelitian dan pembahasan, dapat ditarik kesimpulan sebagai berikut : Pertama, Pelaksanaan manajemen pengembangan mutu lembaga pendidikan di MIN Tempel sudah berorientasi untuk beberapa tahun kedepan mulai dari perencanaan pengorganisasian dan juga pelaksanaan dan pengawasan. Keseluruhan proses telah dilakukan dengan baik dilihat dari rincian kegiatan dan target-target yang ada. Seluruh rincian kegiatan telah terfokus untuk pengembangan mutu lembaga pendidikan MIN Tempel yang mencakup keseluruhan aspek - aspek yang ada. Manajemen pengembangan mutu lembaga yang dilaksanakan di MIN Tempel diantaranya yaitu proses perencanaan yang jelas dan sistematis dalam rangka mewujudkan visi-misi MIN Tempel telah dilakukan dengan baik. Adapun Perencanaan yang dilakukan mengacu kepada standar pendidikan. Wujud dari 
perencanaan tertuang dalam tim pengembangan madrasah yang terdiri dari pengembangan standar kompetensi lulusan, pengembangan standar isi, pengembangan standar proses, pengembangan standar tenaga pendidik dan kependidikan, pengambangan standar sarana dan prasarana, pengembangan standar pengelolaan, pengembangan standar pendidikan, pengembangan standar penilaian, dan pengembangan budaya dan lingkungan. Pengorganisasian merupakan koordinasi yang dilakukan dalam pembagian kerja di MIN Tempel Yogyakarta. Pengawasan merupakan proses yang dilakukan untuk mengawasi pelaksanaan manajemen pengembangan mutu di MIN Tempel Yogyakarta.

Faktor pendukung dan penghambat manajemen pengembangan mutu di MIN Tempel: pertama, faktor internal yang mendukung manajemen pengembangan mutu madrasah ada 4 poin diantaranya yang pertama, Pendidik yang memiliki kualifikasi pendidikan minimal S1 secara akademisi sehingga sangat mendukung dalam pencapaian dan pengembangan pendidikan yang berkualitas. Kedua, Fasilitas yang berupa ruang kelas yang memadai, laboratorium computer, perpustakaan, Ruang UKS, Mushola. Ketiga, Adanya sistim informasi yang memadai baik lewat web maupun secara manual yang dapat digunakan untuk memberikan informasi terkait kegiatan dan program-program MIN Tempel. Keempat, Struktur ogranisasi dan pembagian tugas yang jelas sehingga koordinasi terjalin dengan baik dari berbagai bidang pengembangan.

Kedua, faktor kkternal yang mendukung manajemen pengembangan mutu madrasah ada 4 poin diantaranya yang pertama, adanya dukungan dari kantor wilayah baik dari materiin maupun non materiil. Kedua, letak geografis MIN Tempel yang mudah dijangkau dan dalam lingkup masyarakat padat penduduk. Ketiga, Kerjasama yang dilakukan dengan berbagai pihak untuk melaksanakan berbagai kegiatan misalnya, Percetakan untuk memberikan support pada bidang publikasi dan pemasaran, Puskesmas Ngaglik yang bejerjasama dalam bidang kesehatan dalam rangka pencegahan dan penanggulangan penyakit, Kepolisian Ngaglik yang bekerjasama dalam rangka sosialisasi pencegahan sebagai tindakan prefentif dalam berbagai bidang baik khususnya lalulintas. Keempat, adanya kerjasama yang baik dan terorganisir antara Madrasah dengan Wali Murid yang 
terwujud dalam POMG sehingga informasi - informasi terkait kegiatan siswa dapat tersampaikan dengan baik

Faktor penghambat internal meliputi tiga hal diantaranya yang pertama, pola berfikir guru yang masih belum siap akan perubahan. Kedua, Kurangnya inisiatif pimpinan dalam perumusan program-program kegiatan. Ketiga, Kurangnya Koordinasi dalam ekstra sehingga jumlah guru dan siswa terkadang kurang kondusif dalam proses pembelajaran. Kedua, Faktor Penghambat Eksternal meliputi dua hal diantaranya yang pertama, informasi yang terkadang mendadak terkait perlombaan dari Dinas sehingga persiapan yang dilakukan kurang maksimal, Kedua, status tanah yang sebagian tanah masih ada yang berstatus sewa.

\section{Daftar Pustaka}

Ahmadi, Abu \& Nur Uhbiyati.ilmu pendidikan. Jakarta : Rumka cipta. 2002.

Arikunto, Suharsimi, Manajemen Pendidikan. Yogyakarta : Aditya Media, 2005.

Atmodiwiryo, Soebagio, Manajemen Pendidikan Indonesia, Jakarta : ardizya Jaya, 2000.

Badafal ,Ibrahim, Manajemen Peningkatan Mutu sekolah Dasar, Jakarta : Bumi Aksara, 2009.

Denim ,Sudaarman dan Suparno, Manajemen dan Kepemimpinan Transformal Kekepala sekolah Jakarta : Rineka Cipta, 2009.

Hamalik, Oemar. perencanaan pegajaran berdasarkan pendekatan sistem. jakarta.Bumi aksara.2005.

Huberman, Milles, Michael and Mattew, B. Analisis Data Kualitatif, (terj) Jakarta: UI Press, 1984.

Jahari,Jaja, Amirulloh Sarbini, Manajemen Madrasah : Teori, Strategi, dan Implementasi, Bandung : Alfabeta, 2013.

Moleong , Lexy, Metode Penelitian Kualitatif, Jakarta : Remaja Rosdakarya, 2004

Sudiyono, Manajemen Pendididikan Tinggi, Jakarta : Rineka Cipta, 2004.

Sugiono, Metode Penelitian Kuantitatif, Kualitatif, dan R\&D, Bandung, Alfabeta, 2009

Sukmadinata, Nana Syaodih, Metode Penelitian Pendidikan, Bandung : Remaja Rosdakarya, 2007.

Ulmunir, Misbah, Manajemen Pendidikan. Yogyakarta, Fakultas Tarbiyah, 2010. 
Manajemen Pengembangan...(Alfian) 18

Usman, Husaini, Manajemen, Teori, Praktik dan riset pendidikan, Jakarta : Bumi Aksara, 2006. 